\title{
Natural resources revenue management from global perspective: Critically important institutional factors
}

\author{
Monika Smělá ${ }^{1, *}$, and Jiři Sejkora ${ }^{1}$ \\ ${ }^{1}$ Prague University of Economics and Business, Faculty of International Relations, Department of \\ International Economic Relations, nam.W. Churchilla 1938/4, 13067 Prague 3, Czech Republic
}

\begin{abstract}
Research background: Globally, many countries are dependent on natural resources, for this reason, their revenue management becomes an important aspect for their economies. It is necessary to understand the relations between institutional factors and natural resource revenue management from the global point of view. It means to identify which institutional aspects impact both positively and negatively the revenue management.

Purpose of the article: The purpose of the article is to find out which conditions, or their combinations, regarding the institutional environment, lead to a certain level of revenue management. It means to comprehend which conditions, respectively their combinations, result in both higher and lower levels of revenue management and consequently influence its sustainability.

Methods: Basically, the fuzzy-set qualitative comparative analysis is used to empirically examine the relations between institutional background and the revenue management in natural resource rich economies. The Resource Governance Index, as the global index measuring the quality of governance in individual countries is used as the input for the analysis.

Findings \& Value added: It was found that the individual institutional aspects have diverse effects on revenue management and its resilience. A few sufficient conditions were revealed, accountability, respectively absence of open data, rule of law, government effectiveness, in terms of higher, respectively lower level of revenue management. Political stability and absence of violence were identified as irrelevant conditions in terms of higher level of revenue management. Consistent pathways to reach higher and lower levels of revenue management were found.
\end{abstract}

Keywords: qualitative comparative analysis; institutions; natural resource management

JEL Classification: $Q 28 ; Q 34 ; O 43$

* Corresponding author: $\underline{x s m e m 28 @, v s e . c z}$ 


\section{Introduction}

Alongside with proving the existence of natural resource curse in 1990s (Sachs and Warner, 1995), the fact that countries endowed by natural resources tend to perform in a worse way than the ones without the natural resource deposits, the topic of natural resource revenue management became widely discussed. The researchers aimed at various explanations of this phenomena affecting countries globally over the world. Many explanations were provided, including the theory of the Dutch disease (Torvik, 2001), volatility of commodity prices (Cavalcanti et al., 2012) or poor settings of tax framework.

Apart from these issues, the institutional environment was, and still is, often mentioned in association with natural resource revenue management in many prominent papers (Joshi, 2013, Gupta, 2008, Epremian et al.,2016). Various aspects of institutional background influencing the management of natural resources in a certain way are highlighted, such as armed conflicts (Collier and Hoeffler, 2002, Alao, 2007), corruption (Torvik, 2001, Sala-iMartin and Subramanian, 2003) or rule of law.

For this reason, it is important to understand the relations between institutional aspects and natural resource revenue management, it means to identify which institutional factors impact both positively and negatively the revenue management in countries rich in natural resources. Moreover, the resource revenue management has a global overlap to other areas through institutional channels on the level of individual countries as well as the world. The overlap is quite a broad one, from social sphere to education, treatment with indigenous communities, global tax framework and similarly. This paper aims at this topic as its main goal is to find out which conditions, or their combinations, regarding institutional background, lead to a certain level of revenue management. It means to comprehend which conditions, or their combinations, result in higher and lower levels of resource revenue management and consequently influence its quality.

The method of fuzzy-set qualitative comparative analysis (fsQCA) is used in this paper. The method is based on researching various conditions, or their combinations, leading to the outcome. The concept of sufficient and necessary conditions, the basic concept of qualitative comparative analysis (QCA), is used to identify the aspects arising either in low or high level of resource revenue management. This approach enables us to have a different point of view on the topic contrasting other research having a look either on specific institutional aspect (e.g. Empremian et al., 2016, Gupta, 2008) or the institutional background as a whole (e.g. Bulte et al., 2005, Raagl, 2019).

The paper is based on dataset from the Resource Governance Index (RGI), the global initiative measuring the quality of governance in natural resource sectors. The RGI provides data on three basic areas of oil, gas, and mining industries - value realization, revenue management and enabling environment. This paper deals entirely with areas of revenue management and enabling environment representing the institutional background which reflect the researched field of interest.

\section{Methodology}

The research is based on fuzzy-set comparative qualitative analysis (fsQCA) one of the methods of comparative approach. Originally, QCA was established by Charles Ragin in late 1960s as a method bridging qualitative and quantitative research fields (Ragin, 1987). At the beginning it was based on so called crisp-set values meaning that each case could be given only two values, either membership or non-membership (Skaaning, 2011). Simultaneously with the development of research methods and broadening the areas where QCA was used (to social sciences or business), the classical QCA was adjusted to fsQCA allowing the 
researcher to work with various levels of membership (Ragin, 2008), respectively nonmembership of a certain phenomenon in the outcome.

However, the fsQCA still respects the basic principles of qualitative comparative approach which are rooted in causal complexity. The concept of causal complexity is derived from causal asymmetry, equifinality and conjunctural causation, all of them are associated with the theory of conditions and their combinations (Misangyi, 2016). The logical connections between them are established through the logic of necessary and sufficient conditions. A necessary condition is such a condition that must be present for an outcome to happen (Schneider and Wagemann, 2012). Contrasting this statement, a sufficient condition can produce an outcome itself.

As far as the fsQCA is used in the scope of this paper, the concept of partial membership in the set is used to better illustrate the reality. Therefore, the value 1 represents the "fullyin" the set, the value 0 represents the "fully-out" of the set (Vassinen, 2012). Afterwards, the value of 0.5 is an important one, so called cross-over point, used as a threshold for determining either membership or non-membership in a set (Ragin, 2008, Schneider and Wagemann, 2012). To follow the existing literature on the fsQCA (Ragin, 2008, Kahwati and Kane, 2020), the real standards and knowledge are used for setting the criteria for membership. For this reason, the already existing division of countries into groups according to their level resource revenue management is used as follows: (i) RGI score higher than 74 means good level, (ii) RGI score between 60 and 74 means satisfactory level, (iii) RGI score between 45 and 59 means weak level, (iv) RGI score between 30 and 44 means poor level and (v) RGI score lower than 30 means failing level (NRGI, 2021).

Regarding these values, other important parameters to perform the further analysis are set - consistency and coverage (Ragin, 2008, Woodside, 2011). Consistency illustrates the extent to which cases sharing a condition, or their combination, correspond to presence of a certain outcome. Basically, it shows the cases with a certain outcome. On the contrary, there is coverage, addressing the extent to which a condition, or their combinations, accounts for cases out of the outcome. Consistency of the following research is set at 0.75 so that the results reach a certain level of validity.

The calibration of data is based on the RGI levels of quality of resource revenue management. Following the above-mentioned approach towards the RGI, seven calibration categories are created to determine either membership or non-membership in a set and its extent. Therefore, two extreme categories are set (i) fully in and (ii) fully out the set, afterwards, there are (iii) mostly but not fully in, (iv) more in than out, (v) more out than in and (vi) mostly but not fully out categories. In the middle, (vii) crossover point stands to set membership values.

The following research is built on data concerning two RGI components, namely revenue management and enabling environment, which corresponds to the purpose of the paper. Furthermore, data on their individual subcomponents is used, which correspond to individual conditions. The division of each component is as follows:

Table 1. Division of RGI component - revenue management

\begin{tabular}{|c|c|}
\hline \multicolumn{2}{|c|}{ REVENUE MANAGEMENT } \\
\hline national budgeting & BUDG \\
\hline subnational revenue sharing & REVEN \\
\hline sovereign wealth funds & FUND \\
\hline
\end{tabular}

Source: NRGI (2021), own adaptation. 
Table 2. Division of RGI component - enabling environment

\begin{tabular}{|c|c|}
\hline \multicolumn{2}{|c|}{ ENABLING ENVIRONMENT } \\
\hline open data & DATA \\
\hline political stability and absence of violence & STABIL \\
\hline control of corruption & CORRUP \\
\hline rule of law & RULE \\
\hline regulatory quality & REGUL \\
\hline government effectiveness & EFFECT \\
\hline voice and accountability & ACCOUNT \\
\hline
\end{tabular}

Source: NRGI (2021), own adaptation

Lastly, it is important to mention that the used dataset includes 17 world countries, corresponding to individual cases in the following research. The countries were chosen according to a criterium - completeness of the data in the 2017 Resource Governance Index. Only countries with a full dataset in RGI components of revenue management and enabling environment are incorporated in the research. Moreover, the number of cases is in accordance with the size of dataset used for qualitative comparative approach, which should be from 10 to 50 cases. To fulfil the purpose of the paper, two separate analyses will be performed to find out the conditions and their combinations leading firstly to high level of resource revenue management and secondly to low level of resource revenue management.

\section{Results}

At the beginning it is important to mention one fact which was proved by the analysis. Individual institutional aspects impact the resource revenue management in a different way. This finding is valid for both analyses, it means fsQCA aiming at institutional aspects leading to higher level of revenue management as well to lower performance in this field.

Concerning the identification of institutional aspects impacting the resource revenue management in a positive way, a few conditions were established as necessary ones. Accountability was identified as a necessary condition in terms of budgeting, even six conditions are necessary ones in terms of sovereign wealth funds - accountability, government effectiveness, regulatory quality, rule of law, control of corruption and open data (see Table 3).

Table 3. Necessary and sufficient conditions - part 1

\begin{tabular}{|c|c|c|c|}
\hline & BUDG & REVEN & FUND \\
\hline Condition & Necessary Sufficiency & Necessary Sufficiency & Necessary Sufficiency \\
\hline accoun & 0.8148 & 0.7273 & 0.9091 \\
\hline$\sim$ accoun & 0.4074 & 0.4545 & 0.2727 \\
\hline effect & 0.6481 & 0.4876 & 0.9091 \\
\hline$\sim$ effect & 0.537 & 0.6612 & 0.2727 \\
\hline regul & 0.6296 & 0.5537 & 1 \\
\hline$\sim$ regul & 0.5556 & 0.6446 & 0.0909 \\
\hline rule & 0.6019 & 0.4793 & 0.9091 \\
\hline$\sim$ rule & 0.5648 & 0.6694 & 0.2727 \\
\hline corrup & 0.5926 & 0.5372 & 0.8182 \\
\hline$\sim$ corrup & 0.6111 & 0.6777 & 0.3636 \\
\hline stabil & 0.4259 & 0.3967 & 0.4545 \\
\hline$\sim$ stabil & 0.7222 & 0.7686 & 0.6364 \\
\hline data & 0.6667 & 0.6364 & 0.8182 \\
\hline$\sim$ data & 0.5 & 0.4959 & 0.2727 \\
\hline
\end{tabular}

Source: own calculations by Tosmana v. 1.61 (2021) 
Having a look at combinations of individual conditions generating the desired outcome, meaning high level of resource revenue management, two configurations can result in such an outcome regarding the set level of consistency. As it can be seen from Table 4 and Table 5 , both in terms of national budgeting and subnational revenue sharing, the presence of all institutional aspects can produce higher level of revenue management. The second configuration reaching the same outcome is presence of all the institutional aspects excluding political stability and absence of violence. Unfortunately, any configurations were revealed in terms of sovereign wealth funds as there are too many necessary conditions in this context, as Table 6 illustrates. It means that there is no space for minimization in terms of sovereign wealth funds in the further analysis.

Table 4. Truth table in terms of national budgeting (BUDG) - part 1

\begin{tabular}{|c|c|c|c|c|c|c|c|c|c|}
\hline Country & Accoun & Effect & Regul & Rule & Corrup & Stabil & Data & BUDG & Consistency \\
\hline $\begin{array}{c}\text { Mongolia, } \\
\text { Brazil }\end{array}$ & 1 & 1 & 1 & 1 & 1 & 1 & 1 & 1 & 0.9231 \\
\hline $\begin{array}{c}\text { Colombia, } \\
\text { India, } \\
\text { Indonesia, } \\
\text { Philippines }\end{array}$ & 1 & 1 & 1 & 1 & 1 & 0 & 1 & 1 & 0.7778 \\
\hline $\begin{array}{c}\text { Malaysia, } \\
\text { Ghana }\end{array}$ & 1 & 1 & 1 & 1 & 1 & 1 & 0 & 0 & 0.7000 \\
\hline $\begin{array}{c}\text { Angola, } \\
\text { Chad, } \\
\text { Sudan, } \\
\text { Venezuela, } \\
\text { DRC, Iraq, } \\
\text { South } \\
\text { Sudan }\end{array}$ & 0 & 0 & 0 & 0 & 0 & 0 & 0 & 0 & 0.4250 \\
\hline
\end{tabular}

Source: own calculations by Tosmana v. 1.61 (2021)

Table 5. Truth table in terms of subnational revenue sharing (REVEN) - part 1

\begin{tabular}{|c|c|c|c|c|c|c|c|c|c|}
\hline Country & Accoun & Effect & Regul & Rule & Corrup & Stabil & Data & REVEN & Consistency \\
\hline $\begin{array}{c}\text { Mongolia, } \\
\text { Brazil }\end{array}$ & 1 & 1 & 1 & 1 & 1 & 1 & 1 & 1 & 0.8462 \\
\hline $\begin{array}{c}\text { Colombia, } \\
\text { India, } \\
\text { Indonesia, } \\
\text { Philippines }\end{array}$ & 1 & 1 & 1 & 1 & 1 & 0 & 1 & 1 & 0.8056 \\
\hline $\begin{array}{c}\text { Angola, } \\
\text { Chad, } \\
\text { Sudan, } \\
\text { Venezuela, } \\
\text { DRC, Iraq, } \\
\text { South } \\
\text { Sudan }\end{array}$ & 0 & 0 & 0 & 0 & 0 & 0 & 0 & 0 & 0.5500 \\
\hline $\begin{array}{c}\text { Malaysia, } \\
\text { Ghana }\end{array}$ & 1 & 1 & 1 & 1 & 1 & 1 & 0 & 0 & 0.3000 \\
\hline
\end{tabular}

Source: own calculations by Tosmana v. 1.61 (2021) 
Table 6. Truth table in terms of sovereign wealth funds (FUND) - part 1

\begin{tabular}{|c|c|c|c|c|c|c|c|c|c|}
\hline Country & Accoun & Effect & Regul & Rule & Corrup & Stabil & Data & FUND & Consistency \\
\hline $\begin{array}{c}\text { Malaysia, } \\
\text { Ghana }\end{array}$ & 1 & 1 & 1 & 1 & 1 & 1 & 0 & 0 & 0.3000 \\
\hline $\begin{array}{c}\text { Colombia, } \\
\text { India, } \\
\text { Indonesia, } \\
\text { Philippines }\end{array}$ & 1 & 1 & 1 & 1 & 1 & 0 & 1 & 0 & 0.2778 \\
\hline $\begin{array}{c}\text { Mongolia, } \\
\text { Brazil }\end{array}$ & 1 & 1 & 1 & 1 & 1 & 1 & 1 & 0 & 0.2308 \\
\hline $\begin{array}{c}\text { Angola, } \\
\text { Chad, } \\
\text { Sudan, } \\
\text { Venezuela, } \\
\text { DRC, Iraq, } \\
\text { South } \\
\text { Sudan }\end{array}$ & 0 & 0 & 0 & 0 & 0 & 0 & 0 & 0 & 0.0000 \\
\hline
\end{tabular}

Source: own calculations by Tosmana v. 1.61 (2021)

Based on the above-mentioned pathways leading to the higher level of resource revenue management, it can be assumed that political stability and absence of violence is an irrelevant condition in terms of national budgeting and subnational revenue sharing. This fact was also confirmed by outcomes of minimization tables represented by Table 7 and Table 8 . The higher level of resource revenue management can be produced even without these institutional aspects.

Table 7. Minimalization table - national budgeting - part 1

\begin{tabular}{|c|c|c|c|}
\hline BUDG & Consistency & Coverage & Unique cov. \\
\hline $\begin{array}{c}\text { ACCOUN * EFFECT * REGUL * RULE * } \\
\text { CORRUP * DATA }\end{array}$ & 0,8148 & 0,4074 & \\
\hline $\begin{array}{c}\text { ACCOUN * EFFECT * REGUL * RULE * } \\
\text { CORRUP * DATA }\end{array}$ & 0,8148 & 0,4074 & $* *$ \\
\hline
\end{tabular}

Source: own calculations by Tosmana v. 1.61 (2021)

Table 8. Boolean minimalization table - subnational revenue sharing - part 1

\begin{tabular}{|c|c|c|c|}
\hline REVEN & Consistency & Coverage & Unique cov. \\
\hline $\begin{array}{c}\text { ACCOUN * EFFECT * REGUL * RULE * } \\
\text { CORRUP * DATA }\end{array}$ & 0,7963 & 0,3554 & \\
\hline $\begin{array}{c}\text { ACCOUN * EFFECT * REGUL * RULE * } \\
\text { CORRUP * DATA }\end{array}$ & 0,7963 & 0,3554 & $* *$ \\
\hline
\end{tabular}

Source: own calculations by Tosmana v. 1.61 (2021)

To have a more complex point of view on the researched issue, the interpretation of fsQCA in the opposite direction is needed. It means to find out if there are any conditions, or their combinations, resulting in a lower level of resource revenue management. Having a look at Table 9, a few necessary conditions can be identified also in this point of view. In terms of subnational revenue sharing, the absence of control of corruption and the absence of open data are the necessary conditions. It means that absence of these institutional aspects leads to lower level of revenue management in countries rich in natural resources. The absence of government effectiveness, rule of law and control of corruption are the necessary conditions in terms of national budgeting. 
Table 9. Necessary and sufficient conditions - part 2

\begin{tabular}{|c|c|c|c|}
\hline & BUDG & REVEN & FUND \\
\hline Condition & Necessary Sufficiency & Necessary Sufficiency & Necessary Sufficiency \\
\hline accoun & 0,5141 & 0,5504 & 0,5307 \\
\hline$\sim$ accoun & 0,6549 & 0,6202 & 0,4868 \\
\hline effect & 0,3099 & 0,4109 & 0,3421 \\
\hline$\sim$ effect & 0,8310 & 0,7287 & 0,6754 \\
\hline regul & 0,4085 & 0,4884 & 0,3772 \\
\hline$\sim$ regul & 0,7324 & 0,6977 & 0,6316 \\
\hline rule & 0,3521 & 0,4419 & 0,3553 \\
\hline$\sim$ rule & 0,7746 & 0,6977 & 0,6623 \\
\hline corrup & 0,3803 & 0,4419 & 0,3596 \\
\hline$\sim$ corrup & 0,7746 & 0,7597 & 0,6579 \\
\hline stabil & 0,3944 & 0,4496 & 0,3421 \\
\hline$\sim$ stabil & 0,7183 & 0,7054 & 0,6667 \\
\hline data & 0,3803 & 0,3643 & 0,4035 \\
\hline$\sim$ data & 0,7465 & 0,7597 & 0,6053 \\
\hline
\end{tabular}

Source: own calculations by Tosmana v. 1.61 (2021)

Basically, the pathway to lower level of resource revenue management is the absence of all the researched institutional aspects. As Table 10, Table 11 and Table 12 illustrate, this relation is applied in all three dimensions of revenue management - subnational revenue sharing, sovereign wealth funds and national budgeting. Another interesting configuration resulting in the same outcome is the presence of accountability, government effectiveness, regulatory quality, rule of law, control of corruption and political stability combined with the absence of open data in terms of subnational revenue sharing and national budgeting. In terms of sovereign wealth funds, the importance of presence of both open data and political stability was identified as a consistent pathway cannot be reached without the presence of these two aspects.

Table 10. Truth table in terms of national budgeting (BUDG) - part 2

\begin{tabular}{|c|c|c|c|c|c|c|c|c|c|}
\hline Country & Accoun & Effect & Regul & Rule & Corrup & Stabil & Data & $\sim$ BUDG & Consistency \\
\hline $\begin{array}{c}\text { Angola, } \\
\text { Chad, } \\
\text { Sudan, } \\
\text { Venezuela } \\
\text { DRC, } \\
\text { Iraq, } \\
\text { South } \\
\text { Sudan }\end{array}$ & 0 & 0 & 0 & 0 & 0 & 0 & 0 & 1 & 0.8500 \\
\hline $\begin{array}{c}\text { Colombia, } \\
\text { India, } \\
\text { Indonesia, } \\
\text { Philippine } \\
\text { S }\end{array}$ & 1 & 1 & 1 & 1 & 1 & 0 & 1 & 0 & 0.4444 \\
\hline $\begin{array}{c}\text { Malaysia, } \\
\text { Ghana }\end{array}$ & 1 & 1 & 1 & 1 & 1 & 1 & 0 & 1 & 0.8000 \\
\hline $\begin{array}{c}\text { Mongolia, } \\
\text { Brazil }\end{array}$ & 1 & 1 & 1 & 1 & 1 & 1 & 1 & 0 & 0.5385 \\
\hline
\end{tabular}

Source: own calculations by Tosmana v. 1.61 (2021) 
Table 11. Truth table in terms of subnational revenue sharing (REVEN) - part 2

\begin{tabular}{|c|c|c|c|c|c|c|c|c|c|}
\hline Country & Accoun & Effect & Regul & Rule & Corrup & Stabil & Data & $\sim$ REVEN & Consistency \\
\hline $\begin{array}{c}\text { Angola, } \\
\text { Chad, } \\
\text { Sudan, } \\
\text { Venezuela, } \\
\text { DRC, Iraq, } \\
\text { South } \\
\text { Sudan }\end{array}$ & 0 & 0 & 0 & 0 & 0 & 0 & 0 & 1 & 0.7500 \\
\hline $\begin{array}{c}\text { Colombia, } \\
\text { India, } \\
\text { Indonesia, } \\
\text { Philippines }\end{array}$ & 1 & 1 & 1 & 1 & 1 & 0 & 1 & 0 & 0.5278 \\
\hline $\begin{array}{c}\text { Malaysia, } \\
\text { Ghana }\end{array}$ & 1 & 1 & 1 & 1 & 1 & 1 & 0 & 1 & 1.0000 \\
\hline $\begin{array}{c}\text { Mongolia, } \\
\text { Brazil }\end{array}$ & 1 & 1 & 1 & 1 & 1 & 1 & 1 & 0 & 0.4615 \\
\hline
\end{tabular}

Source: own calculations by Tosmana v. 1.61 (2021)

Table 12. Truth table in terms of sovereign wealth funds (FUND) - part 2

\begin{tabular}{|c|c|c|c|c|c|c|c|c|c|}
\hline Country & Accoun & Effect & Regul & Rule & Corrup & Stabil & Data & $\sim$ FUND & Consistency \\
\hline $\begin{array}{c}\text { Angola, } \\
\text { Chad, } \\
\text { Sudan, } \\
\text { Venezuela, } \\
\text { DRC, Iraq, } \\
\text { South } \\
\text { Sudan }\end{array}$ & 0 & 0 & 0 & 0 & 0 & 0 & 0 & 1 & 1.0000 \\
\hline $\begin{array}{c}\text { Colombia, } \\
\text { India, } \\
\text { Indonesia, } \\
\text { Philippines }\end{array}$ & 1 & 1 & 1 & 1 & 1 & 0 & 1 & 1 & 0.7778 \\
\hline $\begin{array}{c}\text { Malaysia, } \\
\text { Ghana }\end{array}$ & 1 & 1 & 1 & 1 & 1 & 1 & 0 & 1 & 0.9000 \\
\hline $\begin{array}{c}\text { Mongolia, } \\
\text { Brazil }\end{array}$ & 1 & 1 & 1 & 1 & 1 & 1 & 1 & 1 & 1.0000 \\
\hline
\end{tabular}

Source: own calculations by Tosmana v. 1.61 (2021)

Contrasting the analysis of institutional aspects having a positive impact on the resource revenue management, any irrelevant conditions were identified in terms of all three institutional dimensions. Following this fact evident from Table 13, Table 14 and Table 15, it can be concluded that the low level of resource revenue management can be reached by various combinations of individual conditions, however, all the conditions must participate either in the form of membership or non-membership.

Table 13. Minimalization table - national budgeting - part 2

\begin{tabular}{|c|c|c|c|}
\hline BUDG & Consistency & Coverage & Unique cov. \\
\hline $\begin{array}{c}\text { ACCOUN } * \text { EFFECT } * \text { REGUL } * \text { RULE } \\
* \text { CORRUP } * \text { STABIL } * \text { DATA }+ \\
\sim \text { ACCOUN } * \text { EFFECT } * \sim \text { REGUL } * \\
\sim \text { RULE } * \text { CORRUP } * \text { STABIL } \\
\sim \text { DATA }\end{array}$ & 0.8367 & 0.5775 & \\
\hline
\end{tabular}




\begin{tabular}{|c|c|c|c|}
\hline $\begin{array}{c}\sim \text { ACCOUN } * \sim \text { EFFECT } * \sim \text { REGUL } * \\
\sim \text { RULE } * \text { CORRUP } * \sim \text { STABIL } * \\
\sim \text { DATA }\end{array}$ & 0.8500 & 0.4789 & 0.4648 \\
\hline $\begin{array}{l}\text { ACCOUN } * \text { EFFECT } * \text { REGUL } * \text { RULE } \\
* \text { CORRUP } * \text { STABIL } * \sim \text { DATA }\end{array}$ & 0.8000 & 0.1127 & 0.0986 \\
\hline
\end{tabular}

Source: own calculations by Tosmana v. 1.61 (2021)

Table 14. Boolean minimalization table - subnational revenue sharing - part 2

\begin{tabular}{|c|c|c|c|}
\hline REVEN & Consistency & Coverage & Unique cov. \\
\hline $\begin{array}{c}\text { ACCOUN } * \text { EFFECT } * \text { REGUL } * \text { RULE } \\
* \text { CORRUP } * \text { STABIL } * \sim \text { DATA }+ \\
\sim \text { ACCOUN } * \sim \text { EFFECT } * \sim \text { REGUL } * \\
\sim \text { RULE } * \sim \text { CORRUP } * \sim \text { STABIL } * \\
\sim \text { DATA }\end{array}$ & 0.7959 & 0.6047 & \\
\hline $\begin{array}{c}\sim \text { ACCOUN } * \sim \text { EFFECT } * \sim \text { REGUL }^{*} \\
\sim \text { RULE } * \text { CORRUP } * \sim \text { STABIL * } \\
\sim \text { DATA }\end{array}$ & 0.7500 & 0.4651 & 0.4496 \\
\hline $\begin{array}{c}\text { ACCOUN } * \text { EFFECT } * \text { REGUL } * \text { RULE } \\
* \text { CORRUP } * \text { STABIL * DATA }\end{array}$ & 1.0000 & 0.1550 & 0.1395 \\
\hline
\end{tabular}

Source: own calculations by Tosmana v. 1.61 (2021)

Table 15. Boolean minimalization table - sovereign wealth funds

\begin{tabular}{|c|c|c|c|}
\hline FUND & Consistency & Coverage & Unique cov. \\
\hline $\begin{array}{c}\text { ACCOUN * EFFECT * REGUL * } \\
\text { RULE * CORRUP * STABIL + } \\
\text { ACCOUN * EFFECT * REGUL * } \\
\text { RULE * CORRUP * DATA + } \\
\sim \text { ACCOUN * } \sim \text { EFFECT * } \sim \text { REGUL * } \\
\sim \text { RULE* } \sim \text { CORRUP * } \sim \text { STABIL * }_{\sim \text { DATA }}^{*}\end{array}$ & 0.9296 & 0.5789 & \\
\hline $\begin{array}{c}\text { ACCOUN * EFFECT * REGUL * } \\
\text { RULE * CORRUP * STABIL }\end{array}$ & 0.9474 & 0.1579 & $* *$ \\
\hline $\begin{array}{c}\text { ACCOUN * EFFECT * REGUL * } \\
\text { RULE * CORRUP * DATA }\end{array}$ & 0.8519 & 0.2018 & $* *$ \\
\hline $\begin{array}{c}\sim \text { ACCOUN * } \sim \text { EFFECT * REGUL * } \\
\sim \text { RULE * CORRUP * } \sim \text { STABIL * } \\
\sim \text { DATA }\end{array}$ & 1.0000 & 0.3509 & $* *$ \\
\hline
\end{tabular}

Source: own calculations by Tosmana v. 1.61 (2021)

Finally, the results of individual analyses should be summed up. Their results correspond to each other, any biased results were not found. Accountability is a crucial condition for reaching higher level of resource revenue management in terms of national budgeting. All institutional aspects excluding political stability are necessary ones for positively impacting the revenue management in terms of sovereign wealth funds. Consistent pathways were found in both analyses, moreover, they are consistent to each other.

\section{Discussion}

Generally, the conducted research proved that individual institutional factors have diverse impacts on resource revenue management. The chosen approach towards the topic alongside with the research method broadens the point of view on the issue. Moreover, it proves the fact that institutional aspects should not be assessed separately nor from a general 
perspective. The importance of individual institutional factors and their mutual connections is highlighted even in existing literature (Bulte et al., 2005, Raagl, 2019).

Voice and accountability were identified as a necessary conditions to reach a high level of resource revenue management in terms of national budgeting and subnational revenue sharing. This finding is supported by the literature as many authors state that the voice of stakeholders taking part in the mining is very important (Adams et al. 2019, Acosta, 2013). Voice and accountability tend to establish many initiatives promoting other desired effects, such as transparency and disclosure of open data (Mason, 2010). The debate over the mining and associated activities approaches the topic to the public which has consequently overlapped to other areas, besides already mentioned data disclosure, corruption and institutional legitimacy are influenced (Mason, 2010, Gupta, 2008). For these reasons, this aspect plays a crucial role in revenue management in countries endowed by natural resources. Interesting results can be observed in terms of sovereign wealth funds.

In case of high level of revenue management, six necessary conditions were identified, on the contrary any necessary condition was found in analysis aiming at high level of revenue management in terms of sovereign wealth funds. This fact is consistent to the complexity and strict measure when sovereign wealth funds are applied. Furthermore, the negative relations between natural resource endowment in a country and effectiveness in achieving sovereign wealth funds' goal was confirmed. The more reliant a country on natural resources, the less effective is the fund in reaching its goals (Kern, 2007). This fact corresponds to the higher number of necessary conditions as the present of six institutional aspects is needed for high level of revenue management.

Concerning combinations of conditions leading to low level of revenue management, a few necessary conditions were identified. Firstly, they are the absence of government effectiveness, the absence of rule of law and the absence of control of corruption in terms of national budgeting. It means that absence of each aspect itself can result in poor revenue management in resource rich countries. All these institutional factors are highlighted as important ones for the level of revenue governance (Bulte et al., 2005, Sala-i-Martin and Subramanian, 2003). In terms of subnational revenue sharing, the absence of control of corruption and the absence of open data are the necessary conditions. Data openness supports transparency, and it is associated with other positive consequences in the extractive field. If the data is not published openly and it is not provided to public, the level of revenue management is threatened. The same pattern is valid for control of corruption, this aspect is crucial because countries with high natural resource exports tend to evince higher level of fraud activities including corruption (Treisman, 2000).

As certain pathways to reach the outcomes were defined, various combinations of institutional aspects leading to either low or high level of resource revenue management can be derived. In terms of national budgeting and subnational revenue sharing, the combination of all the institutional aspects excluding political stability and absence of violence generate a higher level of revenue management. This shows that the excluded aspect is an irrelevant one as the high level of revenue management can be reached without its presence. The political stability as a single aspect is not pointed out as an important factor in this field, the same statement is valid for absence of violence. Concerning this factor, much research proved the opposite relation, meaning that low level of revenue management tend to provoke more conflicts and violence (Alao, 2007, Hoeffler, 2002).

Following the importance of all the researched institutional factors, one of the pathways to low level of revenue management is evident. It is the absence of all the aspects being affirmed in terms of all three dimensions of RGI. However, open data is a crucial condition in terms of subnational revenue sharing and national budgeting. If the data is not provided in a transparent and open way, the low level of revenue management is reached even though other institutional factors are present. This corresponds to the previously mentioned 
importance of data openness and transparency which are simultaneously transferred to settings of other institutional aspects.

\section{Conclusion}

The paper focuses on the topic of resource revenue management in relation to institutional background, its main purpose is to identify conditions, or their combinations, having both positive and negative aspects on revenue governance in naturally endowed countries. To achieve this goal, two analyses are performed, the method of fuzzy-set qualitative comparative analysis (fsQCA) is chosen for the research. This method enables to reveal the conditions and their combinations leading to the researched outcome, moreover, it helps us to address the issue from a different point of view than majority of existing papers. The dataset from RGI is used as an input for the research, namely the data concerning revenue management and enabling environment is processed.

Firstly, an overview of the qualitative comparative method is introduced so that the basic foundations and logic of conducted fsQCA are known. The basic steps of fsQCA are outlined, including the most important values and parameters on which the following research is built on. In addition, the structure of the RGI dimensions is highlighted for better understanding and orientation in the fsQCA results in section 3. The calibration of the data, on which the analyses are based, is mentioned. This section provides the theoretical background for the provided analyses and their result.

The empirical results are discussed in association with the existing literature, knowledge, and research. Generally, the fact that each institutional aspect impacts the level of revenue governance in a diverse way is confirmed. It also supports the choice of the research method as QCA in general aims at finding out various combinations leading to a certain outcome. In addition, a few necessary and irrelevant conditions were identified. Firstly, voice and accountability is a necessary condition to reach higher level of revenue management in terms of national budgeting and subnational revenue sharing. In terms of sovereign wealth funds, six necessary conditions are present in the context of high level of revenue governance which corresponds to strict measures needed to be applied for effective setting of these funds. Having a look at conditions supporting low level of resource revenue management, the absence of government effectiveness, the absence of rule of law and the absence of control of corruption are identified in terms of national budgeting. In terms of subnational revenue sharing, the absence of control of corruption and the absence of open data are the necessary conditions.

Certain consistence pathways are found in the context of revenue management. Either the presence of all researched institutional factors or all of them excluding political stability and absence of violence can result in high level of revenue management and consequently supports its quality and the extractive industry in general. On the contrary, the absence of all these factors undermines the level of revenue governance. If the open data is not present, but other factors are, the level of revenue governance also decreases in terms of national budgeting and subnational revenue sharing. The same works for the absence of open data alongside with absence of political stability and presence of violence.

\section{References}

1. Acosta, A. M. (2013). The Impact and Effectiveness of Accountability and Transparency Initiatives: The Governance of Natural Resources. Development Policy Review, 31(S1), 89-105. 
2. Adams, D. et al. (2019). Globalisation, governance, accountability, and the natural resource curse: Implications for socio-economic growth of oil-rich developing countries. Resources Policy, 61, 128-140.

3. Alao, A. (2007). Natural Resources and Conflict in Africa. Rochester Studies in African History and the Diaspora.

4. Balin, B. J. 2009. Sovereign Wealth Funds: A Critical Analysis. The John Hopkins University School of Advanced International Studies.

5. Bulte, E. H. et al. (2005). Resource Intensity, Institutions, and Development. World Development, 33(7), 1027-1044.

6. Cavalcanti, Tiago V. de V. et al. (2012). Commodity Price Volatility and the Sources of Growth. IMF Working Paper.

7. Collier, P., \& Hoeffler, A. (2002). Greed and Grievance in Civil War. Centre for the Study of African Economies.

8. Empremian, L. et al. (2016). High-Value Natural Resources and Transparency: Accounting for Revenues and Governance. Oxford Research Encyclopedia of Politics.

9. Gupta, A. (2008). Transparency Under Scrutiny: Information Disclosure in Global Environmental Governance. Global Environmental Politics, 8(2).

10. Joshi, A. (2013). Do They Work? Assessing the Impact of Transparency and Accountability Initiative in Service Delivery. Development Policy Review, 31(S1), 2948.

11. Kahwati L. C., \& Kane H. L. (2020). Qualitative Comparative Analysis in Mixed Methods Research and Evaluation. SAGE Publications.

12. Mason, M. (2008). Transparency for Whom? Information Disclosure and Power in Global Environmental Governance. Global Environmental Politics, 8(2), 8-13.

13. Misangyi, V. (2016). Embracing causal complexity: the emergence of a neoconfigurational perspective. Journal of Management, 43(1), 255-282.

14. NRGI (2021) 2017 Resource Governance Index. https://resourcegovernanceindex.org.

15. Raagl, A. K. (2019). Natural Resources, Institutions, and Economic Growth: The Case of Nigeria. Policy Research Working Paper No 8153. World Bank.

16. Ragin, C. (1987). The comparative method: Moving beyond qualitative and quantitative strategies. University of California Press.

17. Ragin, C. C. (2008). Redesigning social inquiry. The University of Chicago Press.

18. Sachs, J. D., \& Warner A. M. (1995). Natural Resource Abundance and Economic Growth. National Bureau of Economic Research Working Paper Series. 5398.

19. Sala-I-Martin, X., \& Subramanian, A. (2003). Addressing The Natural Resource Curse: An Illustration From Nigeria. NBER Working Paper 9804.

20. Schneider, C., \& Wagemann, C. (2012). Set-theoretic methods for the social sciences. Cambridge University Press.

21. Skaaning, S. (2011). Assesing the robustness of crisp-set anf fuzzy-set QCA results. Sociological Methods and Research, 40(2), 391-408.

22. Torvik, R. (2001). Natural Resources, Rent Seeking and Welfare. Journal Of Development Economics, 67(2002), 455-470.

23. Treisman, D. (2000). The Causes of Corruption: A Cross-National Study. Journal of Public Economics, 76, 399-457.

24. Vassinen, A. (2012) Configurational explanation of marketing outcomes. Aalto University Schoold of Economics.

25. Woodside, A., \& Zhang, M (2011). Identifying x-consumers using causal recipes: "whales" and "jumbo shrimps" casino gamblers. Journal of Gambling Studies, 28(1), 13-26. 